of and the degree to which the last twenty years of both IUCN and WWF have been influenced by Sir Peter Scott would show how very much we are all in the debt of that outstanding conservation virtuoso. But I must not blame the author for writing the book I would have like him to instead of the one his material has enabled him to. For this is a classic instance of a historian's documentary approach - compare John Sheail on the British conservation movement. When one knows how little of most meetings gets into the written record, it is always astonishing that historians are able to learn what really happened from written records. But, supplemented, one must suppose, by a good deal of hearsay and discussion with still living actors, here is an excellent account of how first ICBP, then IUCN and finally WWF came about, and a reasonably detached view of their achievements: CITES, the African Convention and the Polar Bear Convention are among the highlights. But what one cannot get from the documents, or only with great difficulty, is how all these institutional achievements worked out on the ground. How many acres of habitat were saved from devastation? How many species or even populations are still in being that would not have been if ICBP, IUCN and WWF had never existed? These are the questions one would like the author to turn to next.

RICHARD FITTER

\title{
The Oxford Companion to Animal Behaviour, edited by David McFarland. Oxford UP, £17.50.
}

This addition to the Oxford Companions is not, as first inspection might lead one to believe, a dictionary or encyclopaedia, but an introductory handbook to the subject of ethology and is intended as a work of reference for the general reader. It contains over 200 separate articles, written by a team of 70 specialists, on every aspect of the subject and the related disciplines of ecology, genetics, physiology and psychology necessary to give the layman the background of biological knowledge he needs to be able to understand this rapidly expanding subject. Liberal cross-references supplement the information as do the references to original accounts listed in the bibliography.

Particularly helpful for the general reader is an extended article on the history of the study of animal behaviour from the earliest times to the present, and also accounts of the work of pioneers such as Charles Darwin, Konrad Lorenz, Niko Tinbergen and Karl von Frisch. Splendid line illustrations mainly by Tim Halliday complement the text admirably. An index to English names of animals and another to scientific names enable details of investigations into particular species to be found easily.

JOHN CLEGG

\section{Australia's Threatened Plants}

Rare or Threatened Australian Plants, by John Leigh, John Briggs, and William Hartley, published by the Australian National Parks and Wildlife Services, is a revised and substantially enlarged edition of a 1979 paper Plants at Risk in Australia. It includes lists of threatened plants with maps for each Australian state, and of endemic species on Australian islands in the Pacific, Indian and Antarctic Oceans, such as Lord Howe, Norfolk and Macquarie, with notes on their conservation status. The total number of plants to which the title applies is 1206 . Christmas Island in the Indian Ocean has 21 endemic species, some of which are still threatened by the phosphate mining there. (PO Box 636, Canberra City, ACT 2601.)

\section{Making Grassland}

Creating Attractive Grassland using Native Plant Species is the self-explanatory title of a booklet by Terry Wells, Shirley Bell and Alan Frost, obtainable from the Nature Conservancy Council. It tells how to collect seeds (hand gathering, from hay bales, mechanical cutting), how to clean store and label them, how to germinate and propagate them, and how to make up suitable mixtures. $£ 3.20$. 